\title{
Effects of neoadjuvant FOLFIRINOX and gemcitabine-based chemotherapy on cancer cell survival and death in patients with pancreatic ductal adenocarcinoma
}

\author{
Li Xie ${ }^{1,2}$, Leizhou Xia ${ }^{1,2}$, Ulla Klaiber ${ }^{1}$, Milena Sachsenmaier ${ }^{1}$, Ulf Hinz ${ }^{1}$, Frank \\ Bergmann $^{3}$, Oliver Strobel ${ }^{1}$, Markus W. Büchler ${ }^{1}$, John P. Neoptolemos ${ }^{1,2}$, Franco \\ Fortunato $^{1,2, *}$ and Thilo Hackert ${ }^{1, *}$ \\ ${ }^{1}$ Department of General, Visceral and Transplantation Surgery, University Clinic Heidelberg, Germany \\ ${ }^{2}$ Section Surgical Research, University Clinic Heidelberg, Germany \\ ${ }^{3}$ Institute of Pathology, University Clinic Heidelberg, Germany \\ ${ }^{*}$ Co-senior authors
}

Correspondence to: Franco Fortunato, email: Franco.Fortunato@uni-heidelberg.de

Keywords: autophagy; cell death; stroma; neoadjuvant therapy; prognosis

Received: October 11, $2019 \quad$ Accepted: December 05, 2019 Published: December 31, 2019

Copyright: Xie et al. This is an open-access article distributed under the terms of the Creative Commons Attribution License 3.0 (CC BY 3.0), which permits unrestricted use, distribution, and reproduction in any medium, provided the original author and source are credited.

\section{ABSTRACT}

Background: The progression and response to systemic treatment of cancer is substantially dependent on the balance between cancer cell death (apoptosis and necroptosis) and cancer cell survival (autophagy). Although well characterized in experimental systems, the status of cancer cell survival and cell death in human pancreatic ductal adenocarcinoma (PDAC), especially in response to chemotherapy and different types of chemotherapy is poorly described.

Results: The median (95\% confidence interval) survival was 31.6 (24.5-44.5) months after FOLFIRINOX versus 15.8 (2.0-20.5) months after gemcitabine-based therapy $(p=0.039)$. PDAC tissue autophagy was reduced compared to normal pancreata based on reduced BECLIN-1 expression and LC3-Lamp-2 colocalization, whilst necroptosis (RIP-1) was increased. Neoadjuvant therapy was associated with further reduced autophagy based on p62/SQSTM-1 accumulation, and increased necroptosis (RIP3 and pMLKL) and apoptosis (BAX, cleaved CASPASE-9 and CASPASE-3) markers, increased nuclear p65 (NF-KB) and extracellular HMGB1 expression, with greater $\mathrm{CD8}^{+}$Iymphocyte infiltration. Survival was associated with reduced autophagy and increased apoptosis. Necroptosis (RIP-3, PMLKL) and apoptosis (BAX and cleaved CASPASE-9) markers were higher after FOLFIRINOX than gemcitabine-based treatment.

Patients and methods: Cancer cell autophagy, apoptosis, and necroptosis marker expression was compared in pancreatic tissue samples from 51 subjects, comprising four groups: (1) surgical resection for PDAC after FOLFIRINOX $(n=11)$, or (2) after gemcitabine-based $(n=14)$ neoadjuvant therapy, $(3)$ patients undergoing PDAC resection without prior chemotherapy $(n=13)$, and (4) normal pancreata from 13 organ donors. Marker expression was undertaken using semi-automated immunofluorescence-FACS-like analysis, defining PDAC cells by $\mathrm{CK}-7^{+}$expression.

\section{INTRODUCTION}

Pancreatic ductal adenocarcinoma (PDAC) has a rising incidence with poor survival and is set to become the second commonest cause of cancer death [1, 2]. Surgery with adjuvant chemotherapy can provide cure but this is only possible in the $10-15 \%$ with resectable disease [1-4]. Most patients have metastatic disease in whom 
palliative chemotherapy is the mainstay of treatment, which includes combinations with gemcitabine or the FOLFIRINOX comprising folinic acid, 5-fluorouracil (5-FU), irinotecan and oxaliplatin [5-7]. There is increasing interest in neoadjuvant chemotherapy with borderline and locally irresectable disease [8]. Efforts are also focused on identifying specific signatures for different types of chemotherapy [9-13].

Different mechanisms of cell death are involved in the pathogenesis of PDAC and responses and resistance mechanisms to cytotoxicity. The contribution of these mechanisms including autophagy, necroptosis and apoptosis are complex with evolving concepts but with relatively few clinical studies. Cytotoxicity will cause DNA damage and induce apoptosis through the mitochondrial intrinsic pathway involving the activation of BAX-like proteins leading to unregulated calcium entry into the mitochondria with cytochrome $\mathrm{C}$ release, formation of the cytochrome C/APAF-1/CASPASE-9 apoptosome complex, and activation of the effector caspase-3 [14]. Cytotoxicity will also lead to the activation of receptor interacting kinases (RIP)-1 and RIP-3 leading to necrosome assembly, which in turn recruits mixed lineage kinase domain-like protein (MLKL) and its phosphorylation (pMLKL), then leading to necroptosis and the release of damage associated molecular patterns (DAMPs) [15].

More complex is the role of autophagy in the pathogenesis of PDAC and clinical correlates. Recruitment of autophagy-related gene ATG-5 is crucial in the formation of the autophagosome. This involves binding of ATG-5 to ATG12-ATG-16 to mediate the palmitoylation (with phosphatidylethanolamine) of microtubule-associated protein light chain 3 (LC3)-I to membrane-bound LC3-II, on the autophagosome. The p62 protein, also called sequestosome 1 (SQSTM-1), is a cargo receptor that binds ubiquitin on cargo in the phagophore or pre-autophagosome and cooperates with BECLIN-1 to deliver cargo to autophagosomes by docking onto LC3-II. The lysosomal-associated membrane proteins (LAMP)-1 and LAMP-2 and the small GTPase RAB-7 are involved in fusing the lysosome to the autophagosome to form the autolyosome [16]. Deletion of ATG-5 in the pancreas has been shown to increase tumor initiation but decrease tumor progression indicating a tumor stagedependent action of autophagy [17-19]. Fujii et al., reported that activation of autophagy in PDAC was asscoiated with reduced survival [20]. On the other hand, TCGA-databank analysis by Görgülü et al., showed a reduction in ATG-5 copy numbers between human PDAC and normal pancreata, and found reduced survival with lower ATG-5 expression based on immunohistochemistry [19]. It has been highlighted however, that autophagic flux is difficult to measure in human tumor samples [21]. In order to clarify the status of cell survival and cell death in human PDAC we undertook a comprehensive analysis of multiple markers for each type of cell death using immunofluorescence-FACS-like quantitation analysis to objectify expression.

\section{RESULTS}

Clinicopathological variables are shown in Table 1. The grade of tumor differentiation was not determined after neoadjuvant because of the general inconsistency of interpretation. Overall median and 2-year survival was greater in patients given neoadjuvant therapy (Log-Rank $\left.\chi_{\mathrm{df2}}^{2}=6.6492, p=0.0360\right)$ (Figure 1A).

We determined the content of $\mathrm{CK}^{+}$tumor cells within the PDAC and healthy pancreatic tissue using immunofluorescence as previously reported [22-24]. Tumors from patients following neoadjuvant therapy had significantly fewer $\mathrm{CK} 7^{+}$tumor cells compared to tumors from patients without prior chemotherapy (Table 2 and Figure 1B).

Tumors had significantly more stromal collagen-I and activated $\alpha \mathrm{SMA}^{+}$cells per unit area compared to normal tissues with a corresponding higher collagen-I to $\alpha \mathrm{SMA}^{+}$cells ratio, or activated stromal index. There was even greater collagen-I deposition and $\alpha \mathrm{SMA}^{+}$cell activation after chemotherapy, which was especially marked after FOLFIROINOX therapy compared to neoadjuvant gemcitabine (Table 2, Figure 1C-1F). In patients who had neoadjuvant therapy the Activated Stromal Index (ratio $\alpha \mathrm{SMA} /$ collagen), using the median cut off value $=1.3$ for stratification was not associated with survival ( $\left.\log -\operatorname{Rank} \chi_{\mathrm{dfl}}^{2}=0.0105, p=0.9184\right)$.

There was reduced autophagy in human PDAC tissue compared to normal pancreata as shown by decreased expression of BECLIN-1, along with decreased colocalization of LC-3 with LAMP-2. Chemotherapy caused further inhibition as shown by an accumulation of p62/SQSTM-1 in CK-7 $7^{+}$tumor cells (Table 2, Figure $2 \mathrm{~A}-2 \mathrm{E})$. In patients who had neoadjuvant therapy there was increased survival associated with reduced autophagy based on the expression of BECLIN1 (median cut off level $\left.=10, \log -\operatorname{Rank} \chi_{\mathrm{dfl}}^{2}=5.2965, p=0.0214\right)$, and p62/ SQSTM-1 (median cut off level $=80$, Log-Rank $\chi_{\mathrm{df1}}^{2}=$ 4.7197, $p=0.0298)$, and colocalization of LC-3 with LAMP-2 (median cut off level $=21$, Log-Rank $\chi_{\mathrm{dfl}}^{2}=$ $3.7672, p=0.0523)$.

Necroptosis was shown to be increased in human PDAC tissue compared to normal pancreata as shown by increased expression of RIP-1 in CK-7 $7^{+}$cells. Necroptosis was further enhanced with chemotherapy as shown by increased expression of RIP-3 and pMLKL (Table 2, Figure 3A-3C).

Apoptosis was not increased in human PDAC tissue without a therapy compared to normal pancreata. Apoptosis was increased following chemotherapy and was especially marked following chemotherapy with FOLFIRINOX compared to gemcitabine (Table 2, Figure 3D-3F). In patients who had neoadjuvant therapy there was increased survival associated with increased apoptosis based on the expression of BAX (median cut off level = 45.2, Log-Rank $\left.\chi_{\mathrm{df1}}^{2}=16.3416, p<0.0001\right)$. 
Table 1: Clinical, histopathology and survival

\begin{tabular}{|c|c|c|c|c|c|}
\hline Variable & $\begin{array}{l}\text { No neoadjuvant } \\
\text { therapy (control) } \\
(n=13)\end{array}$ & $\begin{array}{c}\text { Three group } \\
\text { comparison } \\
P \text {-value }\end{array}$ & $\begin{array}{l}\text { Gemcitabine- } \\
\text { based neoadjuvant } \\
\text { therapy }(n=14)\end{array}$ & $\begin{array}{c}\text { FOLFIRINOX } \\
\text { neoadjuvant } \\
\text { therapy }(n=11)\end{array}$ & $\begin{array}{c}\text { Gemcitabine vs } \\
\text { FOLFIRINOX } \\
P \text {-value }\end{array}$ \\
\hline Gender & & 0.6528 & & & 1.0 \\
\hline Male & $4(30.8 \%)$ & & $7(50.0 \%)$ & $6(54.5 \%)$ & \\
\hline Female & $9(69.2 \%)$ & & $7(50.0 \%)$ & $5(45.5 \%)$ & \\
\hline $\begin{array}{l}\text { Median age } \\
\text { (years) }\end{array}$ & 59.2 & 0.6747 & 59.6 & 58.4 & 0.3961 \\
\hline range & $40.1-76.7$ & & $45.0-75.1$ & $42.5-71.5$ & \\
\hline T-stage & & 0.2975 & & & 0.2493 \\
\hline pT1/ypT1 & $0(0.0 \%)$ & & $0(0.0 \%)$ & $1(9.1 \%)$ & \\
\hline pT2/ypT2 & $1(7.7 \%)$ & & $0(0.0 \%)$ & $1(9.1 \%)$ & \\
\hline pT3/ypT3 & $12(92.3 \%)$ & & $12(85.7 \%)$ & $9(81.8 \%)$ & \\
\hline pT4/ypT4 & $0(0.0 \%)$ & & $2(14.3 \%)$ & $0(0.0 \%)$ & \\
\hline $\begin{array}{l}\text { Lymph node } \\
\text { stage }\end{array}$ & & 0.0782 & & & 0.6951 \\
\hline pNO/ypNo & $2(15.4 \%)$ & & $8(57.1 \%)$ & $5(45.5 \%)$ & \\
\hline pN1/ypN1 & $11(84.6 \%)$ & & $6(42.9 \%)$ & $6(54.5 \%)$ & \\
\hline $\begin{array}{l}\text { Positive lymph } \\
\text { node number }\end{array}$ & & 0.1148 & & & 0.8545 \\
\hline $\mathbf{0}$ & $2(15.4 \%)$ & & $8(57.1 \%)$ & $5(45.5 \%)$ & \\
\hline $1-3$ & $5(38.5 \%)$ & & $5(35.7 \%)$ & $4(36.4 \%)$ & \\
\hline$\geq 4$ & $6(46.1 \%)$ & & $1(7.1 \%)$ & $2(18.2 \%)$ & \\
\hline Metastasis stage & & 0.2392 & & & 0.6043 \\
\hline М0/урМ0 & $13(100 \%)$ & & $11(78.6 \%)$ & $10(90.9 \%)$ & \\
\hline урМ1 & $0(0.0 \%)$ & & $3(21.4 \%)$ & $1(9.1 \%)$ & \\
\hline Resection margin & & 0.8076 & & & 0.8302 \\
\hline R0 & $4(26.7 \%)$ & & $6(42.9 \%)$ & $4(36.4 \%)$ & \\
\hline $\mathbf{R} 1$ & $9(73.3 \%)$ & & $7(50.0 \%)$ & $7(63.6 \%)$ & \\
\hline $\mathbf{R x}$ & $0(0.0 \%)$ & & $1(7.1 \%)$ & $0(0.0 \%)$ & \\
\hline UICC stage & & 0.0361 & & & 0.5655 \\
\hline UICC Ia & $0(0.0 \%)$ & & $0(0.0 \%)$ & $1(9.1 \%)$ & \\
\hline UICC Ib & $1(7.7 \%)$ & & $0(0.0 \%)$ & $1(9.1 \%)$ & \\
\hline UICC IIa & $1(7.7 \%)$ & & $6(42.9 \%)$ & $3(27.3 \%)$ & \\
\hline UICC IIb & $11(84.6 \%)$ & & $4(28.6 \%)$ & $5(45.5 \%)$ & \\
\hline UICC III & $0(0.0 \%)$ & & $1(7.1 \%)$ & $0(0.0 \%)$ & \\
\hline UICC IV & $0(0.0 \%)$ & & $3(21.4 \%)$ & $1(9.1 \%)$ & \\
\hline \multicolumn{6}{|l|}{ Survival } \\
\hline $\begin{array}{l}\text { Median overall } \\
\text { (months) }\end{array}$ & 31.6 & $\begin{array}{c}\text { Log rank } \\
x_{2 d f}^{2}=6.64\end{array}$ & 15.8 & 39.7 & $\begin{array}{c}\text { Log rank } \\
x_{1 d f}^{2}=64.26\end{array}$ \\
\hline $95 \%$ CI & $24.5-44.5$ & $p=0.0360$ & $2.0-20.5$ & $18.5-59.5$ & $p=0.0390$ \\
\hline 2 Year $(\%)$ & 53.8 & & 21.4 & 79.5 & \\
\hline $95 \% \mathrm{CI}$ & $24.9-76.0$ & & $5.2-44.8$ & $39.3-94.5$ & \\
\hline
\end{tabular}


There was an enhanced inflammatory response in pancreatic tumors and after chemotherapy with a significant increase in extracellular HMGB-1, and stromal infiltration by $\mathrm{CD}-8^{+}$T-lymphocytes in human PDAC tissue. Tumor infiltration by macrophages and neutrophils was significantly increased in tumor tissue compared to controls. Expression of the nuclear transcription factor NFKB p65 in in $\mathrm{CK}-7^{+}$tumor cells was also greatly increased following chemotherapy (Table 2, Figure 4A-4E).

\section{DISCUSSION}

In this study we found that pancreatic cancer epithelial cells had reduced autophagy compared to normal epithelial cells and was further reduced by chemotherapy.
Decreased autophagy induced by chemotherapy was associated with improved survival. FOLFIRINOX also induced greater necroptosis and apoptosis than gemcitabine based-therapy, which may also contribute to longer survival.

Various animal models show that inhibition of autophagy increases DNA damage, suppresses pancreatic cancer cell growth, and involves both tumor cell-intrinsic and host effects [18]. Experimentally the addition of chloroquine to single chemotherapy agents does not always increase treatment efficacy and chloroquine inhibition of autophagy in cancer associated fibroblasts may increase cancer cell resistance to gemcitabine [25]. On the other hand, Bryant et al. have shown that suppression of KRAS or the downstream effectors ERK-MAPK

\section{A}

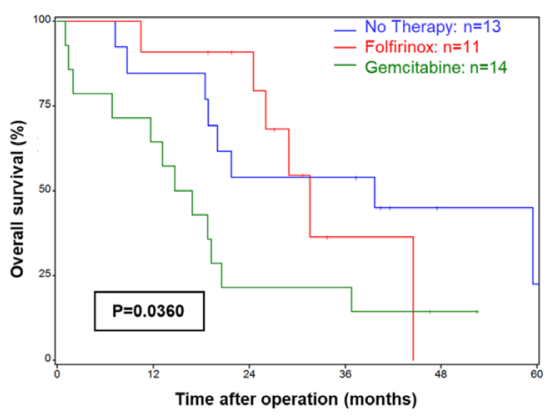

D
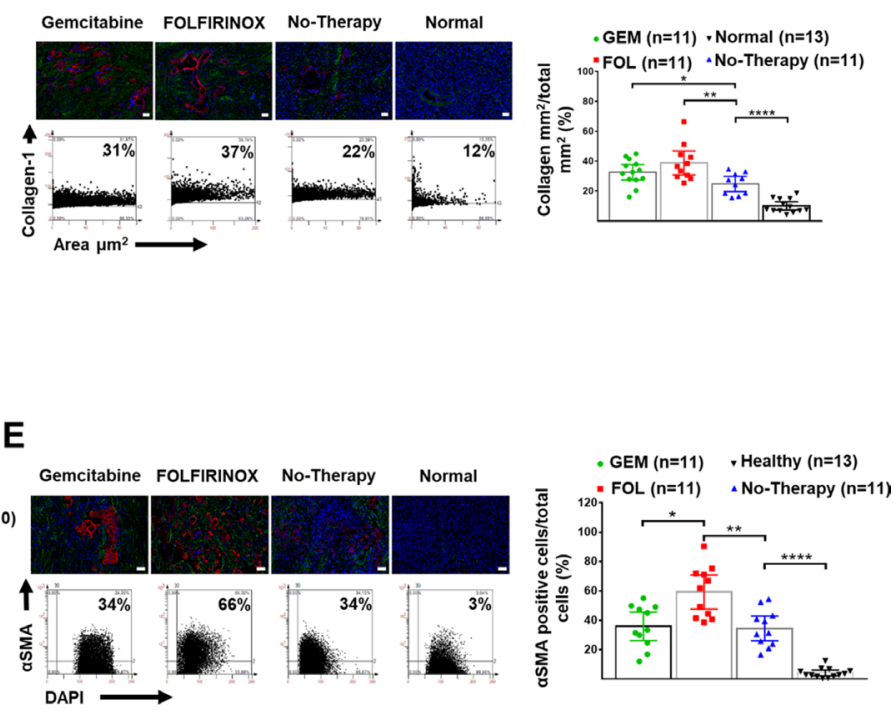

E

B

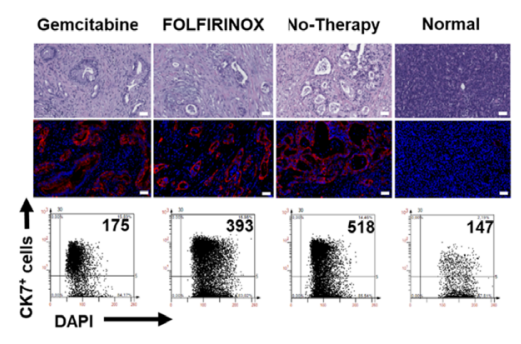

C

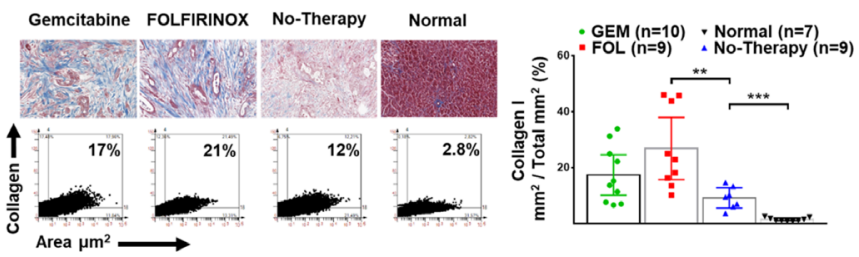

$\mathbf{F}$

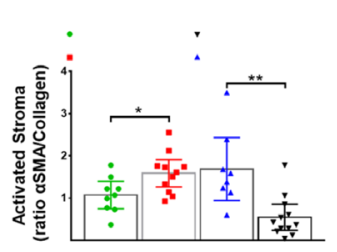

Figure 1: Overall survival and human pancreatic normal tissue and cancer stroma: $H \& E, C K 7+$ cells and expression of collagen-1 and $\alpha$ SMA. (A) Overall survival after resection and neoadjuvant FOLFIRINOX or gemcitabine-based chemotherapy in patients presenting with borderline or non-resectable pancreatic cancer. The median $(95 \%$ confidence interval) survival was 31.6 (24.544.5) months after FOLFIRINOX $(n=11)$ versus $15.8(2.0-20.5)$ months after gemcitabine-based therapy $(n=13)(p=0.039)$. (B) Representative H\&E stained tissues (top), and IF (bottom) for DAPI (blue) and CK- $7^{+}$tumor cells (red), as well as representative FACSlike co-expression scattergrams and quantitation of CK- $7^{+}$cells per area in $\mathrm{mm}^{2}$ are blotted as mean with $95 \% \mathrm{CI}$ as shown in Table 2. (C) Representative trichrome stained tissues for collagen-1, as well as representative FACS-like co-expression scattergrams and quantitation of collagen-1 expression per area $\mathrm{mm}^{2}$ are blotted as mean with $95 \% \mathrm{CI}$ as shown in Table 2. (D) Representative IF stained tissues for collagen-1 (green), DAPI (blue) and CK- $7^{+}$tumor cells (red), as well as representative FACS-like co-expression scattergrams and quantitation of collagen-1 expression per area $\mathrm{mm}^{2}$ are blotted as mean with $95 \% \mathrm{CI}$ as shown in Table 2. (E) Representative IF stained tissues for $\alpha \mathrm{SMA}$ (green), DAPI (blue) and CK- $7^{+}$tumor cells (red), as well as representative FACS-like co-expression scattergrams and quantitation of $\alpha \mathrm{SMA}$ and are blotted as mean with $95 \% \mathrm{CI}$ as shown in Table 2. (F) The mean $(95 \% \mathrm{CI})$ activated stromal index (ratio of $\alpha$ SMA to collagen-1) by group. Human tissue scale bar $=20 \mu \mathrm{m}, 20 \times$ objective. ${ }^{*} P<0.05,{ }^{* *} P<0.01,{ }^{* * *} P<0.001,{ }^{* * * * *} P<0.0001$. 
Table 2: Markers of cell death in normal and pancreatic cancer tissue and following neoadjuvant therapy

\begin{tabular}{|c|c|c|c|c|c|c|c|}
\hline Markers & $\begin{array}{l}\text { Normal } \\
\text { Pancreas } \\
(n=13)\end{array}$ & $\begin{array}{c}{ }^{1} P \text { value } \\
\text { Normal } \\
\text { vs } \\
\text { Control }\end{array}$ & $\begin{array}{c}\text { No neoadjuvant } \\
\text { therapy } \\
(\text { control }) \\
(n=13)\end{array}$ & $\begin{array}{c}\text { Control vs } \\
\text { Gemcitabine vs } \\
\text { FOLFIRINOX } \\
{ }^{2} P\end{array}$ & $\begin{array}{c}\text { Gemcitabine- } \\
\text { based } \\
\text { neoadjuvant } \\
\text { therapy }(n=14)\end{array}$ & $\begin{array}{c}\text { Gemcitabine vs } \\
\text { FOLFIRINOX } \\
{ }^{1} P\end{array}$ & $\begin{array}{c}\text { FOLFIRINOX } \\
\text { neoadjuvant } \\
\text { therapy }(n=11)\end{array}$ \\
\hline & $\begin{array}{l}\text { Median } \\
(95 \% \text { CI })\end{array}$ & & $\begin{array}{l}\text { Median } \\
(95 \% \mathrm{CI})\end{array}$ & & $\begin{array}{l}\text { Median } \\
(95 \% \mathrm{CI})\end{array}$ & & $\begin{array}{l}\text { Median } \\
(95 \% \mathrm{CI})\end{array}$ \\
\hline $\begin{array}{l}\mathrm{CK}^{+} \text {cells / per } \\
\mathrm{mm}^{2}\end{array}$ & $\begin{array}{c}147.0 \\
(8.00-244.0)\end{array}$ & 0.0006 & $\begin{array}{c}518.5 \\
(197.0-673.0)\end{array}$ & 0.0158 & $\begin{array}{c}195.0 \\
(53.00-298.0)\end{array}$ & NS & $\begin{array}{c}393.0 \\
(99.00-773.0)\end{array}$ \\
\hline \multirow{2}{*}{$\begin{array}{l}\text { Collagen mm² } \\
\text { Area } \mathbf{m m}^{2}(\%)\end{array}$} & 7.7 & \multirow{2}{*}{$<0.0001$} & & \multirow{2}{*}{0.0117} & 32.8 & \multirow{2}{*}{ NS } & 36.52 \\
\hline & $(6.87-14.9)$ & & $16.49-32.96$ & & $27.59-41.56$ & & $8.4-51.2$ \\
\hline \multirow{2}{*}{$\begin{array}{l}\alpha \mathrm{SMA}^{+} \text {cells/ total } \\
\text { cells } \%\end{array}$} & & \multirow{2}{*}{$<\mathbf{0 . 0 0 0 1}$} & 31.3 & \multirow{2}{*}{0.0067} & \multirow{2}{*}{33.4} & \multirow{2}{*}{0.0128} & 61.8 \\
\hline & $1.62-6.82$ & & $20.95-52.39$ & & & & $40.73-75.27$ \\
\hline $\begin{array}{l}\text { Ratio } \alpha \text { SMA/ } \\
\text { Collagen }\end{array}$ & $\begin{array}{c}0.400 \\
(0.210-0.850)\end{array}$ & 0.0015 & $\begin{array}{c}1.485 \\
(0.600-3.500)\end{array}$ & NS & $\begin{array}{c}1.070 \\
(0.730-1.500)\end{array}$ & 0.0361 & $\begin{array}{c}1.610 \\
(1.040-2.120)\end{array}$ \\
\hline \multicolumn{8}{|l|}{$\begin{array}{l}\text { Autophagy } \\
\text { Markers }\end{array}$} \\
\hline $\begin{array}{l}\text { p62/SQSTM1 in } \\
\text { CK } 7^{+} \text {cells } \%\end{array}$ & $\begin{array}{c}34.10 \\
(4.70-93.90)\end{array}$ & NS & $\begin{array}{c}53.50 \\
(6.600-77.60)\end{array}$ & 0.0004 & $\begin{array}{c}86.05 \\
(62.50-97.10)\end{array}$ & NS & $\begin{array}{c}94.60 \\
(93.40-98.00)\end{array}$ \\
\hline $\begin{array}{l}\text { BECLIN1 }^{+} \text {cells/ } \\
\text { total cells } \%\end{array}$ & $\begin{array}{c}33.18 \\
(19.16-52.14)\end{array}$ & 0.0056 & $\begin{array}{c}4.032 \\
(0.28-17.67)\end{array}$ & NS & $\begin{array}{c}2.91 \\
(0.34-9.98)\end{array}$ & NS & $\begin{array}{c}5.59 \\
(3.15-15.25)\end{array}$ \\
\hline $\begin{array}{l}\text { ATG5 in } \mathrm{CK}^{+} \\
\text {cells } \%\end{array}$ & $\begin{array}{c}85.79 \\
(72.72-90.85)\end{array}$ & & $\begin{array}{c}84.04 \\
(55.42-90.11)\end{array}$ & NS & $\begin{array}{c}88.34 \\
(75.11-96.05)\end{array}$ & NS & $\begin{array}{c}69.41 \\
(51.40-84.05)\end{array}$ \\
\hline $\begin{array}{l}\text { ATG7 in } \mathrm{CK}^{+} \\
\text {cells } \%\end{array}$ & $\begin{array}{c}56 \\
(36.72-76.20)\end{array}$ & NS & $\begin{array}{c}80 \\
(68.83-93.16)\end{array}$ & NS & $\begin{array}{c}66 \\
(45.25-86.81)\end{array}$ & NS & $\begin{array}{c}61 \\
(38.31-84.73)\end{array}$ \\
\hline $\begin{array}{l}\text { LC3 and } \\
\mathrm{LAMP2}^{+} \text {cells \% }\end{array}$ & $\begin{array}{c}43.82 \\
(14.46-62.21)\end{array}$ & 0.0140 & $\begin{array}{c}12.94 \\
(1.882-41.47)\end{array}$ & NS & $\begin{array}{c}16.03 \\
(0.820-19.73)\end{array}$ & NS & $\begin{array}{c}12.60 \\
(4.793-17.78)\end{array}$ \\
\hline \multicolumn{8}{|l|}{$\begin{array}{l}\text { Necroptosis } \\
\text { Markers }\end{array}$} \\
\hline $\begin{array}{l}\text { RIP1 in } \mathrm{CK}^{+} \\
\text {cells \% }\end{array}$ & $\begin{array}{c}11.07 \\
(4.240-22.39)\end{array}$ & 0.0048 & $\begin{array}{c}71.49 \\
(15.91-78.86)\end{array}$ & NS & $\begin{array}{c}69.31 \\
(44.88-87.36)\end{array}$ & NS & $\begin{array}{c}80.20 \\
(44.85-98.85)\end{array}$ \\
\hline $\begin{array}{l}\text { RIP3 in } \mathrm{CK}^{+} \\
\text {cells } \%\end{array}$ & $\begin{array}{c}7.080 \\
(3.400-64.17)\end{array}$ & NS & $\begin{array}{c}39.48 \\
(6.070-56.72)\end{array}$ & 0.0002 & $\begin{array}{c}70.87 \\
(36.57-90.09)\end{array}$ & 0.0243 & $\begin{array}{c}94.87 \\
(77.00-98.92)\end{array}$ \\
\hline $\begin{array}{l}\text { pMLKL in } \mathrm{CK}^{+} \\
\text {cells } \%\end{array}$ & $\begin{array}{c}3.900 \\
(0.080-14.30)\end{array}$ & NS & $\begin{array}{c}0.4000 \\
(0.150-4.180)\end{array}$ & $<0.0001$ & $\begin{array}{c}4.495 \\
(2.70-16.15)\end{array}$ & 0.0022 & $\begin{array}{c}19.08 \\
(8.60-39.49)\end{array}$ \\
\hline \multicolumn{8}{|l|}{$\begin{array}{l}\text { Apoptosis } \\
\text { Markers }\end{array}$} \\
\hline $\begin{array}{l}\mathrm{BAX} \text { in } \mathrm{CK}^{+} \\
\text {cells } \%\end{array}$ & $\begin{array}{c}14.62 \\
(0.610-40.22)\end{array}$ & NS & $\begin{array}{c}14.53 \\
(3.000-45.15)\end{array}$ & 0.0004 & $\begin{array}{c}44.16 \\
(27.24-73.04)\end{array}$ & 0.0299 & $\begin{array}{c}75.27 \\
(45.05-93.73)\end{array}$ \\
\hline $\begin{array}{l}\text { Cleaved } \\
\text { Caspase-9 in } \\
\text { CK } 7^{+} \text {cells \% }\end{array}$ & $\begin{array}{c}40.46 \\
(2.810-61.67)\end{array}$ & NS & $\begin{array}{c}30.06(6.98- \\
48.42)\end{array}$ & 0.0008 & $\begin{array}{c}61.09 \\
(41.98-78.55)\end{array}$ & 0.0148 & $\begin{array}{c}83.76 \\
(72.77-90.86)\end{array}$ \\
\hline $\begin{array}{l}\text { Caspase-3 in } \\
\text { CK } 7^{+} \text {cells \% }\end{array}$ & $\begin{array}{c}6.100 \\
(0.920-20.01)\end{array}$ & NS & $\begin{array}{c}4.145 \\
(0.540-21.29)\end{array}$ & 0.0007 & $\begin{array}{c}27.97 \\
(11.97-55.40)\end{array}$ & NS & $\begin{array}{c}52.87 \\
(30.50-66.59)\end{array}$ \\
\hline \multicolumn{8}{|l|}{$\begin{array}{l}\text { Inflammatory cell } \\
\text { infiltrate Markers }\end{array}$} \\
\hline $\begin{array}{l}\text { Extracellular } \\
\text { HMGB1 per } \\
\text { area \% }\end{array}$ & $\begin{array}{c}0.720 \\
(0.0671-1.506)\end{array}$ & NS & $\begin{array}{c}1.361 \\
(0.00-2.989)\end{array}$ & 0.0102 & $\begin{array}{c}3.027 \\
(1.004-19.36)\end{array}$ & NS & $\begin{array}{c}3.424 \\
(1.558-23.14)\end{array}$ \\
\hline Macro- $\Phi$ cells \% & $\begin{array}{c}0.205 \\
(0.110-0.590)\end{array}$ & 0.0052 & $\begin{array}{c}0.870 \\
(0.410-5.270)\end{array}$ & NS & $\begin{array}{c}1.430 \\
(0.910-2.060)\end{array}$ & NS & $\begin{array}{c}1.340 \\
(0.530-5.270)\end{array}$ \\
\hline $\mathrm{CD8}^{+}$cells \% & $\begin{array}{c}0.39 \\
(0.25-0.74)\end{array}$ & NS & $\begin{array}{c}0.95 \\
(0.43-1.47)\end{array}$ & 0.0016 & $\begin{array}{c}2.05 \\
(1.11-4.65)\end{array}$ & NS & $\begin{array}{c}4.06 \\
(2.61-6.48)\end{array}$ \\
\hline $\begin{array}{l}\text { MPO Expression } \\
\%\end{array}$ & $\begin{array}{c}0.175 \\
(0.090-0.920)\end{array}$ & 0.0205 & $\begin{array}{c}0.665 \\
(0.230-1.94)\end{array}$ & NS & $\begin{array}{c}0.65 \\
(0.37-2.810)\end{array}$ & NS & $\begin{array}{c}2.00 \\
(0.680-4.540)\end{array}$ \\
\hline $\begin{array}{l}\text { NF-кB p65 in } \\
\text { CK } 7^{+} \text {cells \% }\end{array}$ & $\begin{array}{c}19.01 \\
(1.85-38.06)\end{array}$ & NS & $\begin{array}{c}33.37 \\
(7.93-61.66)\end{array}$ & 0.0008 & $\begin{array}{c}80.20 \\
(70.24-92.29)\end{array}$ & NS & $\begin{array}{c}83.81 \\
(53.91-89.33)\end{array}$ \\
\hline
\end{tabular}

12 tailed Mann-Whitney $U$ test; ${ }^{2}$ Kruskal-Wallis test. 
increased autophagic flux, with decreased glycolytic and mitochondrial functions, and that inhibition of both ERKMAPK and autophagy may be an effective treatment for PDAC [26].

Studies of cell survival and cell death in patients with PDAC with clinical outcomes are relatively few. In 2008 Fujii S, et al. found that strong LC3 expression in the peripheral area of resected pancreatic cancer tissue was associated with reduced survival compared to weak or negative expression [20]. Koh et al. also reported that BECLIN-1 overexpression was associated with poor prognosis [27]. Boone et al. in a phase I/II trial of neoadjuvant hydroxyl-chloroquine with gemcitabine in 35 patients with PDAC, found that patients who had more than a $51 \%$ increase in LC3-II in circulating peripheral blood mononuclear cells had an improvement in overall survival but no assessment was made of in the resected tumor specimens [28]. Görgülü et al., also reported that lower levels of ATG5 were associated with both tumor metastasis and shorter survival time [19].

This is the only study in humans to compare a range of autophagy proteins in normal pancreata, untreated PDAC tissues and in PDAC tissues after two types of commonly used chemotherapy. The results demonstrated a reduction in autophagy by neoadjuvant chemotherapy compared to untreated PDAC, and longer survival associated with reduced autophagy. Unlike the study of Görgülü et al., we found no association between survival and expression of ATG-5 and ATG- 7 in $\mathrm{CK} 7^{+}$cells, whilst the other autophagy markers indicated an opposite finding.

There may be a number of reasons for his discrepancy including different methodologies and different patient cohorts. Our findings support the conclusion from experimental studies that reduced autophagy, whether intrinsic, genetically, or pharmacologically induced, is associated with improved survival [18, 26, 28-31].
A

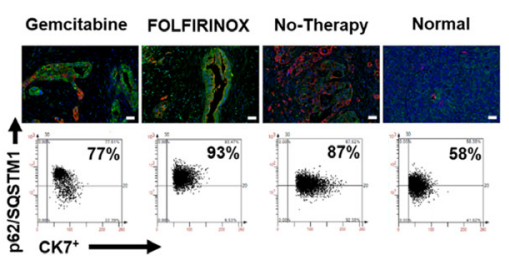

B

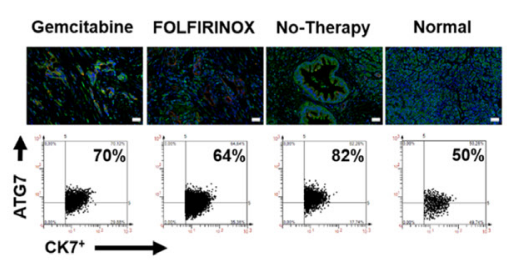

C

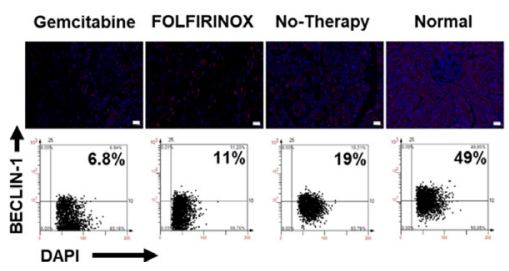

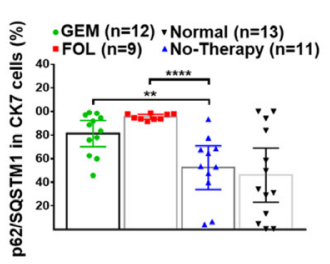

สูํ․
D
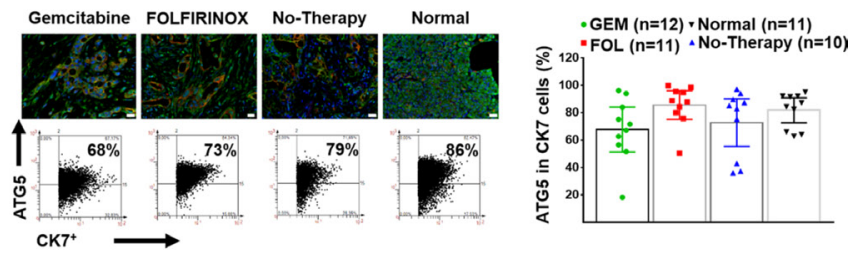

E
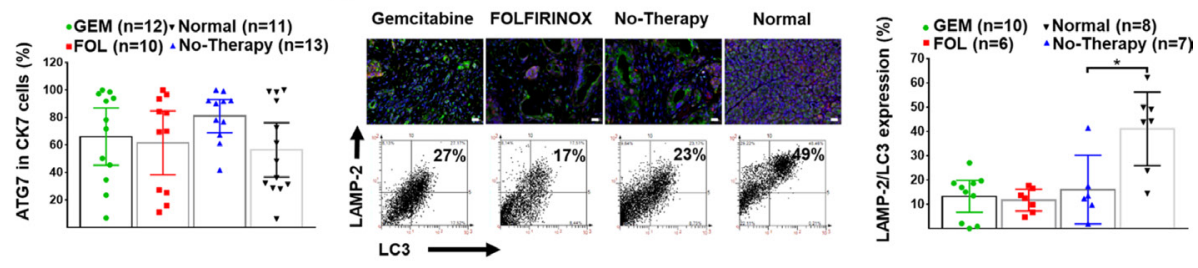

Figure 2: Human pancreatic normal and cancer tissues: expression of autophagy markers. (A) Representative IF-stained tissues for DAPI (blue), CK-7 $7^{+}$tumor cells (red) and p62/SQSTM-1 (green), as well as representative FACS-like co-expression scattergrams and quantitation of p62/SQSTM-1 in CK-7 $7^{+}$tumor cells are blotted as mean with 95\% CI as shown in Table 2. (B) Representative IF-stained tissues for ATG-7 (green), DAPI (blue), and CK-7 $7^{+}$tumor cells (red), as well as representative FACS-like co-expression scattergrams and quantitation of ATG-7 in CK-7 $7^{+}$tumor cells are blotted as mean with 95\% CI as shown in Table 2. (C) Representative IF-stained tissues with or for BECLIN-1 (red) and DAPI (blue), as well as representative FACS-like co-expression scattergrams and quantitation of BECLIN-1 in DAPI cells are blotted as mean with 95\% CI as shown in Table 2. (D) Representative IF-stained tissues for ATG-5 (green), DAPI (blue), and CK- $7^{+}$tumor cells (red), as well as representative FACS-like co-expression scattergrams and quantitation of ATG-5 in CK- $7^{+}$tumor cells are blotted as mean with 95\% CI as shown in Table 2. (E) Representative IF-stained tissues for LAMP-2 (red), LC-3 (green) and DAPI (blue), as well as representative FACS-like co-expression scattergrams and quantitation of LC-3 with LAMP-2 are blotted as mean with 95\% CI as shown in Table 2 . Human tissue scale bar $=20 \mu \mathrm{m}, 20 \times$ objective. ${ }^{*} P<0.05,{ }^{* *} P<0.01,{ }^{* * *} P<0.001,{ }^{* * * *} P<0.0001$. 
We found no significant association between the activated stromal index (ratio $\alpha \mathrm{SMA} /$ collagen) and survival, and perhaps more surprisingly no difference between chemo-naive PDAC and post induction chemotherapy [32]. We found that neoadjuvant therapy was associated with further increased necroptosis and apoptosis marker expression as well as increased nuclear p65 $(\mathrm{NF}-\kappa \mathrm{B})$ and extracellular HMGB1 expression. Moreover necroptosis and apoptosis markers were higher after FOLFIRINOX than gemcitabine-based treatment reflecting the better respective response and survival rates [4-8]. These findings are largely original in human PDAC tissue. It was interesting to see that necroptosis was particularly induced by neoadjuvant FOLFIRINOX as this mechanism may overcome intrinsic or gemcitabine induced resistance to apoptosis. It should be noted that excess necroptosis with DAMPs, may result protumorigenic inflammation and immunosuppression [15].
The necrosome may represent an important therapeutic target for PDAC as necroptosis, may be pharmacologically induced by the aurora kinase inhibitor CCT137690 [33]. Although PDAC is highly resistant to apoptosis, this study showed a considerable increase in apoptosis with chemotherapy which was greatest with FOLFIRINOX [14, 34]. Longer survival was also associated with increased apoptosis. There were significantly more tumor infiltrating $\mathrm{CD}^{+}$cytotoxic $\mathrm{T}$ lymphocytes after neoadjuvant therapy which favors improved survival $[35,36]$.

Taken together these results indicate a favorable response to neoadjuvant chemotherapy and in particular FOLFIRINOX, including reduced autophagy, and increased necroptosis, apoptosis and $\mathrm{CD}^{+}$tumor infiltration. We found that decreased PDAC tissue autophagy and increased apoptosis, were associated with longer survival after neoadjuvant chemotherapy. These findings support targeting autophagy as a therapeutic strategy against
A

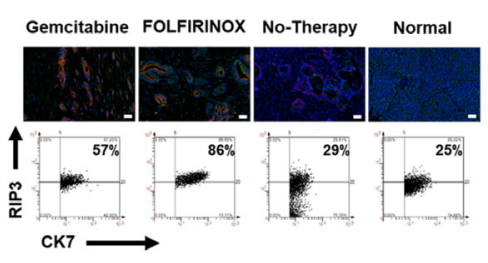

B

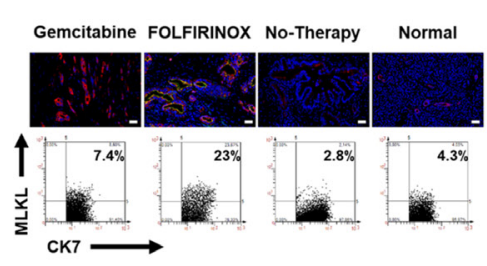

C

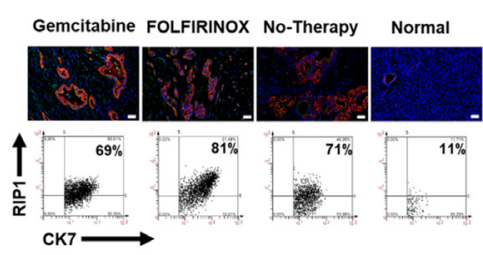

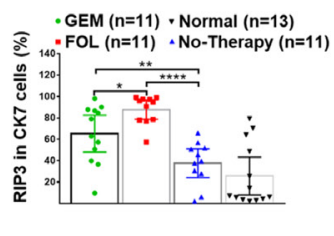

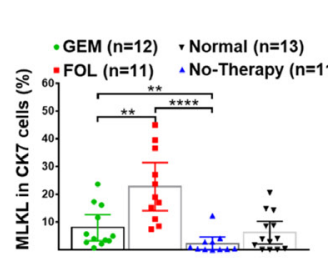

D
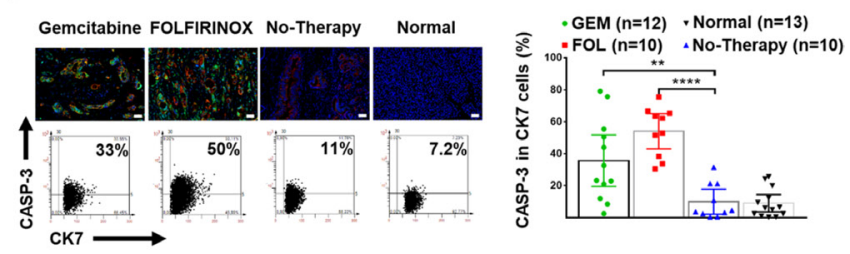

E
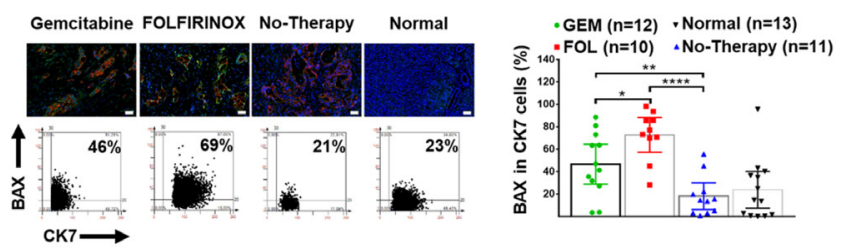

$\mathbf{F}$

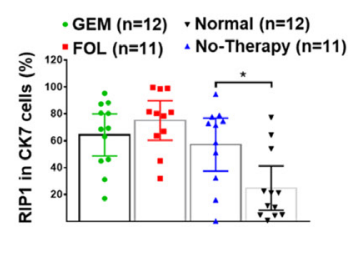

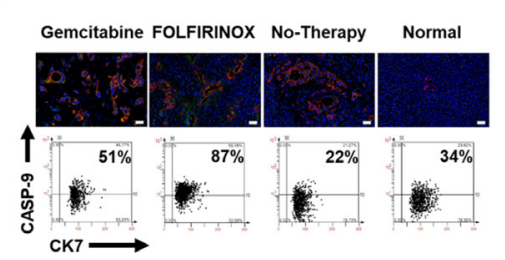

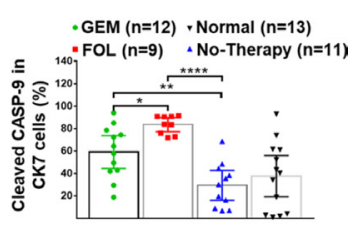

Figure 3: Human pancreatic normal and cancer tissues: expression of necroptosis and apoptosis markers. (A) Representative IF-stained tissues for DAPI (blue), CK-7+ tumor cells (red), and RIP-3 (green), as well as representative FACS-like co-expression scattergrams and quantitation of RIP-3 in CK- $7^{+}$tumor cells are blotted as mean with $95 \%$ CI as shown in Table 2 . (B) Representative IF-stained tissues for DAPI (blue), CK- $7^{+}$tumor cells (red), and pMLKL (green), as well as representative FACS-like co-expression scattergrams and quantitation of pMLKL in CK-7 $7^{+}$tumor cells are blotted as mean with $95 \%$ CI as shown in Table 2 . (C) Representative IF-stained tissues for DAPI (blue), CK- $7^{+}$tumor cells (red), and RIP-1 (green), as well as representative FACS-like co-expression scattergrams and quantitation of RIP-1 in CK- $7^{+}$tumor cells are blotted as mean with $95 \%$ CI as shown in Table 2. (D) Representative IF-stained tissues for CASPASE-3 (green), DAPI (blue) and CK-7 tumor cells (red), as well as representative FACS-like co-expression scattergrams and quantitation of CASPASE-3 in $\mathrm{CK}^{+}$tumor cells are blotted as mean with $95 \%$ CI as shown in Table 2 . (E) Representative images of pancreatic tumor stained for BAX (green), DAPI (blue) and CK $7^{+}$tumor cells (red) as well as representative FACS-like co-expression scattergrams and quantitation of BAX in $\mathrm{CK} 7^{+}$tumor cells are blotted as mean with $95 \% \mathrm{CI}$ as shown in Table 2 . (F) Representative images of pancreatic tumor tissue stained for cleaved CASPASE-9 (green), DAPI (blue) and CK $7^{+}$tumor cells (red), as well as representative FACS-like co-expression scattergrams and quantitation of CASPASE-9 in CK $7^{+}$tumor cells are blotted as mean with 95\% CI as shown in Table 2. Human tissue scale bar $=20 \mu \mathrm{m}, 20 \times$ objective. ${ }^{*} P<0.05,{ }^{* *} P<0.01,{ }^{* * *} P<0.001,{ }^{* * * *} P<0.0001$. 
pancreatic cancer. In addition, clinical studies testing antiautophagy therapies should employ a range of cancer tissue autophagy markers.

\section{MATERIALS AND METHODS}

\section{Patients and study design}

We identified four groups from the pancreas clinical database and biobank at the Department of Surgery, Heidelberg: (1) patients with initially locally advanced unresectable PDAC (without metastases) who then had surgical resection after FOLFIRINOX $(n=11)$ neoadjuvant therapy, (2) similar patients with initially unresectable PDAC who then had surgical resection for PDAC after gemcitabine-based $(n=14)$ neoadjuvant therapy, (3) patients who had resectable PDAC at presentation and had up-front surgical resection without prior chemotherapy $(n=13)$, and (4) normal pancreata from 13 organ donors. We only included patients with
PDAC who had good quality tumor tissue and who had completed a full neoadjuvant course of either FOLFIRINOX or gemcitabine-based chemotherapy. Clinic-pathological variables including survival time were only analyzed at the completion of the study and were not assessed in the selection procedure.

The overall median survival was compared in the two groups with unresectable PDAC and related to the expression of cell death markers. The survival of patients with resectable PDAC is also provided but cannot be directly compared survival of with the patients with initially non-resectable tumors. This study was approved by the Ethics Committee of Heidelberg University (Ethics Committee Approval No. 301/2001, renewed 2012).

\section{Histopathology}

Fresh tissue samples were immediately fixed in $4 \%$ buffered formalin for approximately $24 \mathrm{~h}$, then immersed in $70 \%$ ethanol for 2 days and embedded by paraffin

\section{A}

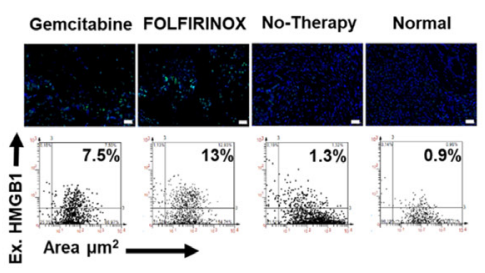

B
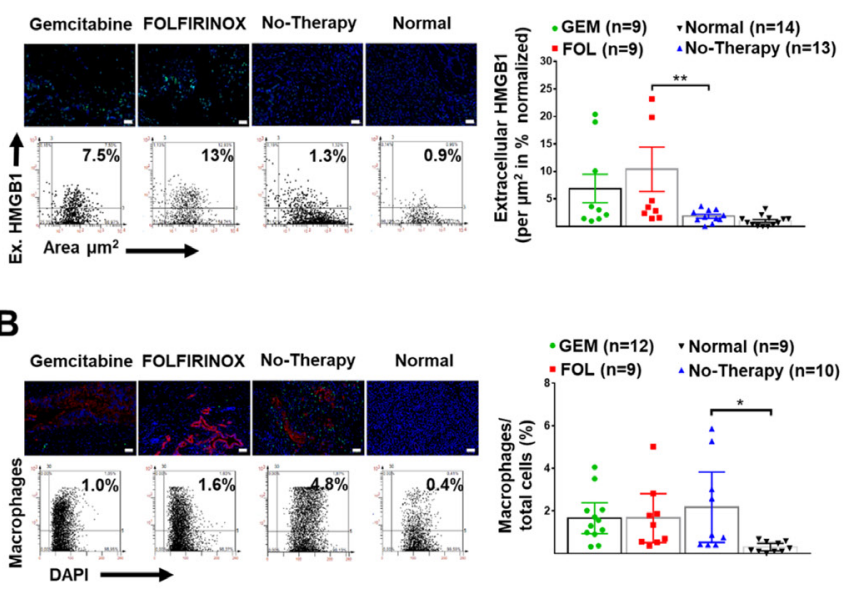

\section{D}
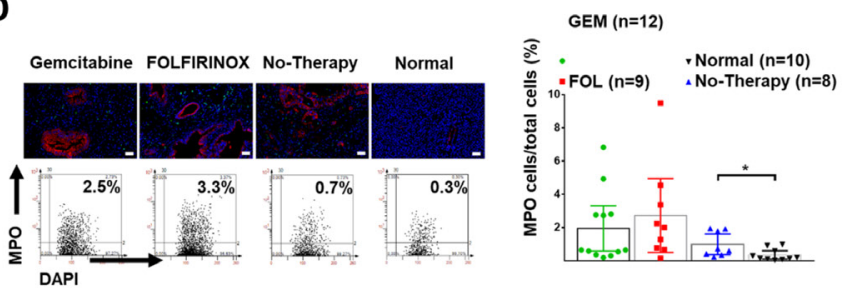

E
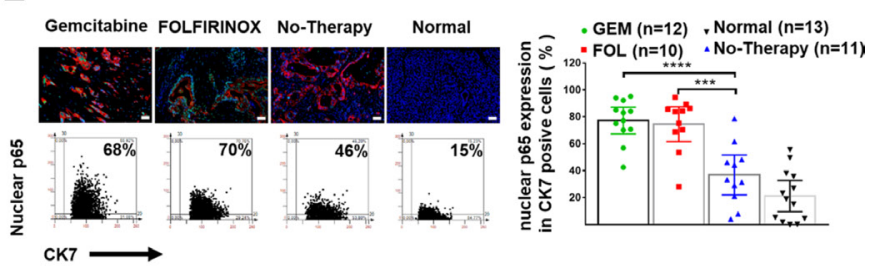

C

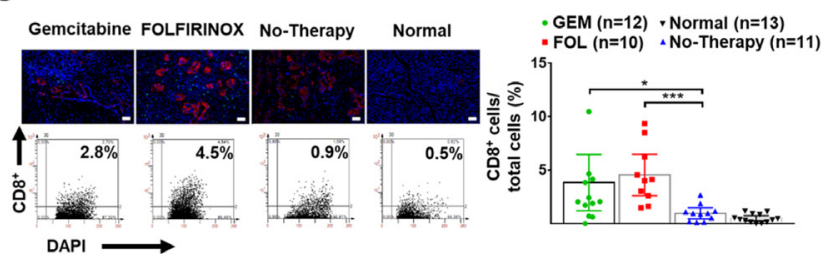

Figure 4: Enhanced Inflammation after neoadjuvant therapy. (A) Representative images of human pancreatic tissue stained for DAPI (blue) and extracellular HMGB1 (green), as well as representative FACS-like scattergrams and quantitation values of normalized extracellular HMGB1 expression per tissue area are blotted as mean with 95\% CI as shown in Table 2. (B) Representative images of human pancreatic tissue stained for DAPI (blue), macrophages (green) and CK $7^{+}$tumor cells (red), as well as representative FACS-like scattergrams and quantitation values of macrophages are blotted as mean with 95\% CI as shown in Table 2. (C) Representative images of human pancreatic tissue stained for DAPI (blue), CD8 ${ }^{+}$TILs (green) and CK $7^{+}$tumor cells (red) as well as representative FACSlike scattergrams and quantitation of $\mathrm{CD}^{+}$TILs are blotted as mean with $95 \% \mathrm{CI}$ as shown in Table 2. (D) Representative images of human pancreatic tissue stained for MPO (green), (green), DAPI (blue) and CK $7^{+}$tumor cells (red), as well as representative FACS-like scattergrams and quantitation values of MPO are blotted as mean with $95 \%$ CI and shown in Table 2. (E) Representative images of human pancreatic tissue stained for nuclear p65 (part of NFKB) (green), DAPI (blue) and CK $7^{+}$tumor cells (red) as well as representative FACSlike scattergrams and quantitation values of nuclear p65 are blotted as mean with $95 \% \mathrm{CI}$ and shown in Table 2 . (Scale bar $=20 \mu \mathrm{m}, 20 \times$ objective). ${ }^{*} P<0.05,{ }^{* *} P<0.01,{ }^{* * *} P<0.001,{ }^{* * * *} P<0.0001$. 
into blocks. The formalin-fixed paraffin-embedded (FFPE) blocks were stored at $4^{\circ} \mathrm{C}$ and then cut into 4 $\mu \mathrm{m}$ thick sections using a Leica microtome and stained with Hematoxylin (H) (VWR International Darmstadt, Germany) and Eosin (E) (Carl Roth, Karlsruhe, Germany).

Tumor specimens and $\mathrm{H}$ and $\mathrm{E}$ slides were checked for diagnosis and tumor cellularity in the Department of Pathology, and anonymised. Staging was undertaken using the UICC 7th Edition [37]. Masson-Goldner's trichrome staining kit (Carl Roth, Karlsruhe, Germany) was used to stain for collagen- 1 and $\alpha$-smooth-muscle actin ( $\alpha \mathrm{SMA})$ in order to determine activated stroma index [32].

Antibodies were chosen for immunofluorescence (IF) to permit quantification of PDAC epithelial cells using cytokeratin (CK)-7 expression [24]. The autophagy markers used included BECLIN-1, ATG-5 and ATG-7. We also used p62/SQSTM-1 as a marker of autophagic flux as levels accumulate when autophagy is inhibited, and are reduced when autophagy is activated [38]. There are no antibodies that distinguish LC3-I from LC3-II, and so colocalization of LC-3 with LAMP-2 was used to indicate autophagy activation with the formation of autolysosomes [16]. The necroptosis markers used were RIP1 and RIP3 and pMLKL. The apoptosis markers used were BAX, CASPASE-3 and cleaved CASPASE-9. As well as using antibodies for identifying stromal infiltration by macrophages, and CD- $8^{+}$lymphocytes, we also used myeloperoxidase (MPO) staining to determine inflammatory cell infiltration. We included detection of high-mobility group box 1 (HMGB-1), which is associated with autophagy and is a DAMP molecule [39]. We included a marker for NF- $\mathrm{B}$ p65, which activates the receptor for advanced glycation end products (RAGE) under stress, and induces autophagy [40].

\section{Immunofluorescence}

FFPE $4 \mu \mathrm{m}$ thin sections were deparaffinised and rehydrated with Roticlear and Ethanol series (Carl Roth, Karlsruhe, Germany). Antigen retrieval was achieved by placing the sections in sodium citrate buffer in a water bath at $98^{\circ} \mathrm{C}$ for $10 \mathrm{~min}$. After cooling at $20^{\circ} \mathrm{C}$ for $30 \mathrm{~min}$, the sections were rinsed in Tris-buffered saline (TBS) for $5 \mathrm{~min}$ and permeabilized with $0.1 \%$ saponin in TBS at $20^{\circ} \mathrm{C}$ for $20 \mathrm{~min}$. The sections were washed with $0.05 \%$ Tween-20 in TBS for $2 \mathrm{~min}$ and then circumscribed with a Cytomation Dako Pen (Dako, Hamburg, Germany). Target specific primary antibodies were incubated in antibody diluent solution (Dako, Hamburg, Germany) for $30 \mathrm{~min}$ at $37^{\circ} \mathrm{C}$ in a dark humidified chamber, followed by several steps of washing. Sections were then incubated with secondary anti-mouse Cy5 and/or anti-rabbit $\mathrm{Cy} 3$ and/or goat-Cy2 labelled antibodies for $30 \mathrm{~min}$ at $20^{\circ} \mathrm{C}$, followed by several steps of washing and incubation with nuclei counterstained using 4'-6-diamidino-2-phenylindole (DAPI) for 20 min. The sections were mounted in Fluoromount-G Reagent (Southern Biotech, Birmingham, AL, USA). We used the TissueGnostics Fluorescence Imaging System (TissueGnostics, Vienna, Austria), with a fluorescence microscope unit (Observer. Z1, Zeiss), and an X-Cite ${ }^{\circledR}$ Series 120PC dynamic fluorescence illuminator (X-Cite ${ }^{\circledR}$, Ontarioo, Canada). The TissueFAXS Imaging Software module automatically captured images by a $20 \times$ objective using different channels to detect the target proteins, with controlling filters, exposure, camera (PCO, Kehlheim, Germany), and motor stage (Märzhäuser, Wetzlar, Germany). StrataQuest Analysis Software (TissueGnostics, Vienna, Austria) was used to produce FACS-like analysis quantitation from IF images, comparing Cy3 (green) and/ or Cy5 (red) intensity with DAPI intensity. Cy5- and Cy3positive cells were gated in the scattergrams according to negative controls without primary antibody. We also used this system to acquire the images of H\&E and trichrome staining and has been described previously [16, 41-43].

\section{Antibodies and reagents}

For immunofluorescence we used the following antibodies. $\alpha-S M A$ (sc-32251), CK7 (sc-23876), p62/ SQSTM1 (sc-25575), BECLIN1 (sc-48341), ATG7 (sc8668), BAX (sc-526), LAMP-2 (sc-5571), macrophage marker (sc-66204), and Erk1/2 (sc-154) were all purchased from Santa Cruz Biotechnology (Heidelberg, Germany). Anti-Collagen-1 (ab-34710) was purchased from Abgent (San Diego, USA). Collagen-I (ab-34710), ATG5 (AP1812a), LC3 (AM1800a), RIP3 (ab-72106), p-MLKL (ab-187091), CASPASE-3 (ab-2171), HMGB1 (ab12029), CD8 (ab-4055), and MPO (ab-9535) were purchased from Abgent (San Diego, USA). RIP1 (NPB1-77077), cleaved CASPASE-9 (NB100-56118), and NF- $\mathrm{B}$ p65 (Ser276) (SAB-11011) were purchased from Novus Biologicals (Cambridge, UK). Secondary anti-rabbit Cy3- or Cy5conjugated and anti-mouse $\mathrm{Cy} 3$ - or Cy5- conjugated antibodies were purchased from Medac $\mathrm{GmbH}$ (Wedel, Germany). All other chemicals, unless stated otherwise, were obtained from Merck, Darmstadt, Germany.

\section{Statistical analysis}

We estimated overall survival using the KaplanMeier method, determined from the date of pancreatic surgery to the censor point or death from any cause. Median survival times and 3-year survival rates with 95\% confidence intervals (CI) are presented, using the log-rank test for comparison. Continuous variables are presented as the median with $95 \%$ CI, with comparison by the KruskalWallis test for multiple groups and the Mann-Whitney $U$ test for two group comparisons. Significance was set at a two-sided $p \leq 0.05$. We used GraphPad Prism 6 and SAS software, Release 9.4, SAS Institute, Inc, Cary, NC, USA. The graphs were presented as the mean with $95 \% \mathrm{CI}$. All results were reported as median $95 \% \mathrm{CI}$, as indicated with the significance score $\left({ }^{*}<0.05 ;{ }^{* *}<0.01 ;{ }^{* * *}<0.001\right.$, $\left.{ }^{* * * *}<0.0001\right)$ in the figure legends. 


\section{Author contributions}

FF, MWB and TH undertook the design of the study. Li Xie, Leizhou Xia and FF performed most of the experiments. Provision of clinical data and interpretation was made by UK, MS, OS, JPN, TH, and MWB. Pathology of human and animal tissues was undertaken by FB. Statistics was undertaken by UH. The manuscript was written by Li Xie, Leizhou Xia, TH, JPN and FF. All authors reviewed the data and analysis, read the manuscript, and agreed with this version for submission.

\section{ACKNOWLEDGMENTS}

We thank the service support from members of the European Pancreas Center (EPZ) - Biobank and Pancobank in Heidelberg, Klaus Felix, Nathalia Giese, Miriam Schenk, Karin Ruf, Sonja Bauer, Bruni Bentzingern, Monika Meinhardt, Markus Herbst, Kathrin Schneider, Markus Stauch and Susann Wendler, and Wolfgang Groß and Michael Schäfer for information technology support.

\section{CONFLICTS OF INTEREST}

The authors declare that they have no affiliations with any financial or non-financial interest in the subject matter or materials discussed in this manuscript.

\section{FUNDING}

This study was supported by the German Research Foundation (Deutsch Forschungs-gemeinschaft, DFG) Excellent Initiative Frontier award to FF. The Biobank of the European Pancreas Center (EPZ), Department of General Surgery, University Hospital Heidelberg, is supported by the Heidelberger Stiftung Chirurgie (MWB), and the German Ministry for Education and Research (Bundesministeriums für Bildung und Forschung, BMBF) grants $01 \mathrm{GS} 08114$ and $01 \mathrm{ZX} 1305 \mathrm{C}$ to $\mathrm{TH}$, Nathalia Giese, and MWB.

\section{REFERENCES}

1. Siegel RL, Miller KD, Jemal A. Cancer statistics, 2019. CA Cancer J Clin. 2019; 69:7-34. https://doi.org/10.3322/ caac.21551. [PubMed]

2. Kleeff J, Korc M, Apte M, La Vecchia C, Johnson CD, Biankin AV, Neale RE, Tempero M, Tuveson DA, Hruban RH, Neoptolemos JP. Pancreatic cancer. Nat Rev Dis Primers. 2016; 2:16022. https://doi.org/10.1038/ nrdp.2016.22. [PubMed]

3. Neoptolemos JP, Palmer DH, Ghaneh P, Psarelli EE, Valle JW, Halloran CM, Faluyi O, O'Reilly DA, Cunningham D, Wadsley J, Darby S, Meyer T, Gillmore R, et al. Comparison of adjuvant gemcitabine and capecitabine with gemcitabine monotherapy in patients with resected pancreatic cancer (ESPAC-4): a multicentre, open-label, randomised, phase 3 trial. Lancet. 2017; 389:1011-1024. https://doi.org/10.1016/ S0140-6736(16)32409-6. [PubMed]

4. Conroy T, Hammel P, Hebbar M, Ben Abdelghani M, Wei AC, Raoul JL, Choné L, Francois E, Artru P, Biagi JJ, Lecomte T, Assenat E, Faroux R, et al. FOLFIRINOX or Gemcitabine as Adjuvant Therapy for Pancreatic Cancer. N Engl J Med. 2018; 379:2395-2406. https://doi.org/10.1056/ NEJMoa1809775. [PubMed]

5. Cunningham D, Chau I, Stocken DD, Valle JW, Smith D, Steward W, Harper PG, Dunn J, Tudur-Smith C, West J, Falk S, Crellin A, Adab F, et al. Phase III randomized comparison of gemcitabine versus gemcitabine plus capecitabine in patients with advanced pancreatic cancer. J Clin Oncol. 2009; 27:5513-5518. https://doi.org/10.1200/ JCO.2009.24.2446. [PubMed]

6. Conroy T, Desseigne F, Ychou M, Bouché O, Guimbaud R, Bécouarn Y, Adenis A, Raoul JL, Gourgou-Bourgade S, de la Fouchardière C, Bennouna J, Bachet JB, KhemissaAkouz $\mathrm{F}$, et al. FOLFIRINOX versus gemcitabine for metastatic pancreatic cancer. N Engl J Med. 2011; 364:1817-1825. https://doi.org/10.1056/NEJMoa1011923. [PubMed]

7. Von Hoff DD, Ervin T, Arena FP, Chiorean EG, Infante J, Moore M, Seay T, Tjulandin SA, Ma WW, Saleh MN, Harris M, Reni M, Dowden S, et al. Increased survival in pancreatic cancer with nab-paclitaxel plus gemcitabine. N Engl J Med. 2013; 369:1691-1703. https://doi.org/10.1056/ NEJMoa1304369. [PubMed]

8. Hackert T, Sachsenmaier M, Hinz U, Schneider L, Michalski CW, Springfeld C, Strobel O, Jäger D, Ulrich A, Büchler MW. Locally Advanced Pancreatic Cancer: Neoadjuvant Therapy With Folfirinox Results in Resectability in 60\% of the Patients. Ann Surg. 2016; 264:457-463. https://doi. org/10.1097/SLA.0000000000001850. [PubMed]

9. Neoptolemos JP, Kleeff J, Michl P, Costello E, Greenhalf W, Palmer DH. Therapeutic developments in pancreatic cancer: current and future perspectives. Nat Rev Gastroenterol Hepatol. 2018; 15:333-348. https://doi.org/10.1038/s41575018-0005-x. [PubMed]

10. Greenhalf W, Ghaneh P, Neoptolemos JP, Palmer DH, Cox TF, Lamb RF, Garner E, Campbell F, Mackey JR, Costello E, Moore MJ, Valle JW, McDonald AC, et al. Pancreatic cancer hENT1 expression and survival from gemcitabine in patients from the ESPAC-3 trial. J Natl Cancer Inst. 2014; 106:djt347. https://doi.org/10.1093/jnci/djt347. [PubMed]

11. Martinelli P, Carrillo-de Santa Pau E, Cox T, Sainz B Jr, Dusetti N, Greenhalf W, Rinaldi L, Costello E, Ghaneh P, Malats N, Büchler M, Pajic M, Biankin AV, et al. GATA6 regulates EMT and tumour dissemination, and is a marker of response to adjuvant chemotherapy in pancreatic cancer. Gut. 2017; 66:1665-1676. https://doi.org/10.1136/ gutjnl-2015-311256. [PubMed] 
12. Aung KL, Fischer SE, Denroche RE, Jang GH, Dodd A, Creighton S, Southwood B, Liang SB, Chadwick D, Zhang A, O'Kane GM, Albaba H, Moura S, et al. Genomics-Driven Precision Medicine for Advanced Pancreatic Cancer: Early Results from the COMPASS Trial. Clin Cancer Res. 2018; 24:1344-1354. https://doi.org/10.1158/1078-0432.CCR-172994. [PubMed]

13. Tiriac H, Belleau P, Engle DD, Plenker D, Deschênes A, Somerville TDD, Froeling FEM, Burkhart RA, Denroche RE, Jang GH, Miyabayashi K, Young CM, Patel H, et al. Organoid Profiling Identifies Common Responders to Chemotherapy in Pancreatic Cancer. Cancer Discov. 2018; 8:1112-1129. https://doi.org/10.1158/2159-8290.CD-180349. [PubMed]

14. Schniewind B, Christgen M, Kurdow R, Haye S, Kremer B, Kalthoff H, Ungefroren H. Resistance of pancreatic cancer to gemcitabine treatment is dependent on mitochondriamediated apoptosis. Int J Cancer. 2004; 109:182-188. https://doi.org/10.1002/ijc.11679. [PubMed]

15. Seifert L, Werba G, Tiwari S, Giao Ly NN, Alothman S, Alqunaibit D, Avanzi A, Barilla R, Daley D, Greco SH, Torres-Hernandez A, Pergamo M, Ochi A, et al. The necrosome promotes pancreatic oncogenesis via CXCL1 and Mincle-induced immune suppression. Nature. 2016; 532:245-249. $\quad$ https://doi.org/10.1038/nature17403. [PubMed]

16. Fortunato F, Bürgers H, Bergmann F, Rieger P, Büchler MW, Kroemer G, Werner J. Impaired autolysosome formation correlates with Lamp-2 depletion: role of apoptosis, autophagy, and necrosis in pancreatitis. Gastroenterology. 2009; 137:350-360. https://doi. org/10.1053/j.gastro.2009.04.003. [PubMed]

17. Rosenfeldt MT, O'Prey J, Morton JP, Nixon C, MacKay G, Mrowinska A, Au A, Rai TS, Zheng L, Ridgway R, Adams PD, Anderson KI, Gottlieb E, et al. p53 status determines the role of autophagy in pancreatic tumour development. Nature. 2013; 504:296-300. https://doi.org/10.1038/ nature12865. [PubMed]

18. Yang S, Kimmelman AC. A critical role for autophagy in pancreatic cancer. Autophagy. 2011; 7:912-913. https://doi. org/10.4161/auto.7.8.15762. [PubMed]

19. Görgülü K, Diakopoulos KN, Ai J, Schoeps B, Kabacaoglu D, Karpathaki AF, Ciecielski KJ, Kaya-Aksoy E, Ruess DA, Berninger A, Kowalska M, Stevanovic M, Wörmann SM, et al. Levels of the Autophagy-Related 5 Protein Affect Progression and Metastasis of Pancreatic Tumors in Mice. Gastroenterology. 2019; 156:203-217.e20. https://doi. org/10.1053/j.gastro.2018.09.053. [PubMed]

20. Fujii S, Mitsunaga S, Yamazaki M, Hasebe T, Ishii G, Kojima M, Kinoshita T, Ueno T, Esumi H, Ochiai A. Autophagy is activated in pancreatic cancer cells and correlates with poor patient outcome. Cancer Sci. 2008; 99:1813-1819. https://doi.org/10.1111/j.13497006.2008.00893.x. [PubMed]
21. Amaravadi R, Kimmelman AC, White E. Recent insights into the function of autophagy in cancer. Genes Dev. 2016; 30:1913-1930. https://doi.org/10.1101/gad.287524.116. [PubMed]

22. Lee MJ, Lee HS, Kim WH, Choi Y, Yang M. Expression of mucins and cytokeratins in primary carcinomas of the digestive system. Mod Pathol. 2003; 16:403-410. https:// doi.org/10.1097/01.MP.0000067683.84284.66. [PubMed]

23. Goldstein NS, Bassi D. Cytokeratins 7, 17, and 20 reactivity in pancreatic and ampulla of vater adenocarcinomas. Percentage of positivity and distribution is affected by the cut-point threshold. Am J Clin Pathol. 2001; 115:695702. https://doi.org/10.1309/1NCM-46QX-3B5T-7XHR. [PubMed]

24. Duval JV, Savas L, Banner BF. Expression of cytokeratins 7 and 20 in carcinomas of the extrahepatic biliary tract, pancreas, and gallbladder. Arch Pathol Lab Med. 2000; 124:1196-1200. [ubMed]

25. Molejon MI, Swayden M, Fanale D, Bintz J, Gayet O, Soubeyran P, Iovanna J. Chloroquine plays a celldependent role in the response to treatment of pancreatic adenocarcinoma. Oncotarget. 2018; 9:30837-30846. https:// doi.org/10.18632/oncotarget.25745. [PubMed]

26. Bryant KL, Stalnecker CA, Zeitouni D, Klomp JE, Peng S, Tikunov AP, Gunda V, Pierobon M, Waters AM, George SD, Tomar G, Papke B, Hobbs GA. Combination of ERK and autophagy inhibition as a treatment approach for pancreatic cancer. Nat Med. 2019; 25:628-640. https://doi. org/10.1038/s41591-019-0368-8. [PubMed]

27. Ko YH, Cho YS, Won HS, Jeon EK, An HJ, Hong SU, Park JH, Lee MA. Prognostic significance of autophagyrelated protein expression in resected pancreatic ductal adenocarcinoma. Pancreas. 2013; 42:829-835. https://doi. org/10.1097/MPA.0b013e318279d0dc. [PubMed]

28. Boone BA, Bahary N, Zureikat AH, Moser AJ, Normolle DP, Wu WC, Singhi AD, Bao P, Bartlett DL, Liotta LA, Espina V, Loughran P, Lotze MT, Zeh HJ 3rd. Safety and Biologic Response of Pre-operative Autophagy Inhibition in Combination with Gemcitabine in Patients with Pancreatic Adenocarcinoma. Ann Surg Oncol. 2015; 22:4402-4410. https://doi.org/10.1245/s10434-015-4566-4. [PubMed]

29. Yang S, Wang X, Contino G, Liesa M, Sahin E, Ying H, Bause A, Li Y, Stommel JM, Dell'antonio G, Mautner J, Tonon G, Haigis M. Pancreatic cancers require autophagy for tumor growth. Genes Dev. 2011; 25:717-729. https:// doi.org/10.1101/gad.2016111. [PubMed]

30. Samaras P, Tusup M, Nguyen-Kim TDL, Seifert B, Bachmann H, von Moos R, Knuth A, Pascolo S. Phase I study of a chloroquine-gemcitabine combination in patients with metastatic or unresectable pancreatic cancer. Cancer Chemother Pharmacol. 2017; 80:1005-1012. https://doi. org/10.1007/s00280-017-3446-y. [PubMed]

31. Yang A, Herter-Sprie G, Zhang H, Lin EY, Biancur D, Wang X, Deng J, Hai J, Yang S, Wong KK, Kimmelman 
AC. Autophagy Sustains Pancreatic Cancer Growth through Both Cell-Autonomous and Nonautonomous Mechanisms. Cancer Discov. 2018; 8:276-287. https://doi. org/10.1158/2159-8290.CD-17-0952. [ $\underline{\text { PubMed] }}$

32. Erkan M, Michalski CW, Rieder S, Reiser-Erkan C, Abiatari I, Kolb A, Giese NA, Esposito I, Friess H, Kleeff $\mathrm{J}$. The activated stroma index is a novel and independent prognostic marker in pancreatic ductal adenocarcinoma. Clin Gastroenterol Hepatol. 2008; 6:1155-1161. https://doi. org/10.1016/j.cgh.2008.05.006. [PubMed]

33. Xie Y, Zhu S, Zhong M, Yang M, Sun X, Liu J, Kroemer G, Lotze M, Zeh HJ 3rd, Kang R, Tang D. Inhibition of Aurora Kinase A Induces Necroptosis in Pancreatic Carcinoma. Gastroenterology. 2017; 153:1429-1443.e5. https://doi. org/10.1053/j.gastro.2017.07.036. [PubMed]

34. Wang L, Zhang Y, Wang W, Zhu Y, Chen Y, Tian B. Gemcitabine treatment induces endoplasmic reticular (ER) stress and subsequently upregulates urokinase plasminogen activator (uPA) to block mitochondrial-dependent apoptosis in Panc-1 cancer stem-like cells (CSCs). PLoS One. 2017; 12:e0184110. https://doi.org/10.1371/journal.pone.0184110. [PubMed]

35. Janakiram NB, Mohammed A, Bryant $\mathrm{T}$, Ritchie R, Stratton N, Jackson L, Lightfoot S, Benbrook DM, Asch AS, Lang ML, Rao CV. Loss of natural killer T cells promotes pancreatic cancer in LSL-Kras $(\mathrm{G} 12 \mathrm{D} /+)$ mice. Immunology. 2017; 152:36-51. https://doi.org/10.1111/ imm.12746. [PubMed]

36. Lohneis $\mathrm{P}$, Sinn M, Bischoff S, Jühling A, Pelzer U, Wislocka L, Bahra M, Sinn BV, Denkert C, Oettle H, Bläker H, Riess H, Jöhrens K, et al. Cytotoxic tumour-infiltrating $\mathrm{T}$ lymphocytes influence outcome in resected pancreatic ductal adenocarcinoma. Eur J Cancer. 2017; 83:290-301. https://doi.org/10.1016/j.ejca.2017.06.016. [PubMed]
37. Sobin LH, Gospodarowicz MK, Wittekind C. TNM Classification of Malignant Tumours, 7th ed. Oxford: Wiley-Blackwell; 2011.

38. Bjørkøy G, Lamark T, Pankiv S, Øvervatn A, Brech A, Johansen T. Monitoring autophagic degradation of p62/ SQSTM1. Methods Enzymol. 2009; 452:181-197. https:// doi.org/10.1016/S0076-6879(08)03612-4. [PubMed]

39. Kang R, Xie Y, Zhang Q, Hou W, Jiang Q, Zhu S, Liu J, Zeng D, Wang H, Bartlett DL, Billiar TR, Zeh HJ 3rd, Lotze MT, Tang D. Intracellular HMGB1 as a novel tumor suppressor of pancreatic cancer. Cell Res. 2017; 27:916932. https://doi.org/10.1038/cr.2017.51. [PubMed]

40. Kang R, Hou W, Zhang Q, Chen R, Lee YJ, Bartlett DL, Lotze MT, Tang D, Zeh HJ. RAGE is essential for oncogenic KRAS-mediated hypoxic signaling in pancreatic cancer. Cell Death Dis. 2014; 5:e1480. https:// doi.org/10.1038/cddis.2014.445. [PubMed]

41. Zhou X, Xie L, Bergmann F, Endris V, Strobel O, Büchler MW, Kroemer G, Hackert T, Fortunato F. The bile acid receptor FXR attenuates acinar cell autophagy in chronic pancreatitis. Cell Death Discov. 2017; 3:1-9. https://doi. org/10.1038/cddiscovery.2017.27. [PubMed]

42. Gu H, Fortunato F, Bergmann F, Büchler MW, Whitcomb DC, Werner J. Alcohol exacerbates LPS-induced fibrosis in subclinical acute pancreatitis. Am J Pathol. 2013; 183:15081517. https://doi.org/10.1016/j.ajpath.2013.07.023. [PubMed]

43. Gu H, Werner J, Bergmann F, Whitcomb DC, Büchler MW, Fortunato F. Necro-inflammatory response of pancreatic acinar cells in the pathogenesis of acute alcoholic pancreatitis. Cell Death Dis. 2013; 4:e816. https://doi. org/10.1038/cddis.2013.354. [PubMed] 